\begin{tabular}{|c|c|c|c|c|}
\hline Prosiding & ISSN : 2581- & Vol 6, No: 2 & Hal: $123-180$ & Juli 2019 \\
$\begin{array}{c}\text { Penelitian \& } \\
\text { Pengabdian }\end{array}$ & 1126 p ISSN: & 2442-448X & & \\
Kepada & & & \\
Masyarakat & & & \\
\hline
\end{tabular}

\title{
ASSERTVENESS TRAINING UNTUK MENINGKATKAN KEPERCAYAAN DIRI NARAPIDANA REMAJA
}

\author{
Meilanny Budiarti Santoso dan Putri Saeza Ramadhini \\ 1,2IImu Kesejahteraan Sosial FISIP-Universitas Padjadjaran \\ meilannybudiarti13@gmail.com; saezaputri@yahoo.com
}

\begin{abstract}
Abstrak
Perkembangan diri anak untuk melewati masa remaja akan dipengaruhi oleh interaksi sosial dirinya dengan lingkungan fisik dan sosial di sekitarnya. Dalam hal ini, anak akan menghadapi situasi lingkungan fisik dan sosial yang baru di Lembaga Pembinaan Khusus Anak dan kehidupan bermasyarakat dengan situasi dan kondisi yang berbeda terhadap dirinya selepas keluar dari Lembaga Pembinaan Khusus Anak. Dalam situasi demikian, remaja membutuhkan pendampingan untuk membantu mereka agar dapat tetap percaya diri dan dapat berkomunikasi dengan baik terutama di hadapan umum. Metode yang digunakan dalam melakukan kegiatan assertiveness training ini adalah dengan menggunakan metodologi pelatihanan dragogi. Hasil yang diperoleh dengan dilakukannya assertiveness training dan proses pendampingan terhadap klien adalah bahwa klien telah mampu untuk mengekspresikan pikiran, perasaan, dan kebutuhan dirinya, baik secara verbal maupunnon verbal, tanpa perasaan takut, cemas, dan khawatir. Klien juga mampu untuk berkomunikasi secara terbuka, langsung, terus terang sebagaimana mestinya.
\end{abstract}

Kata kunci:assertiveness training, kepercayaandiri, remaja

\begin{abstract}
The child's self-development to get through adolescence will be influenced by his social interaction with physical and social environment around him. In this case, the child will face a new physical and social environment situation in Lembaga Pemasyarakatan Khusus Anak (LPKA) and social life with different situations and conditions for him after leaving Lembaga Pemasyarakatan Khusus Anak (LPKA). In such situations, adolescents need assistance to help them to remain confident and able to communicate well, especially in public. The method used in conducting this assertiveness training activity is to use the Dragogy training methodology. The results obtained by doing assertiveness training and mentoring process to the client is that the client has been able to express his thoughts, feelings, and needs, both verbally and nonverbally, without feeling afraid, anxious, and worried. Clients are also able to communicate openly, directly, as framkly as they should.
\end{abstract}

Keyword: assertiveness training, confidence, teenagers

\section{Pendahuluan}

World Health Organization (WHO) memperkirakan jumlah populasi remaja dunia sekitar $1 / 5$ (satu per lima) dari total jumlah penduduk dunia, keadaan tersebut dalam beberapa tahun terakhir menimbulkan terjadinya pergeseran pola penyebab tindak 


\begin{tabular}{|c|c|c|c|c|}
\hline Prosiding & e ISSN : 2581- & & & \\
Penelitian \& & Vol 6, No: 2 & Hal: $123-180$ & Juli 2019 \\
$\begin{array}{c}\text { Pengabdian } \\
\text { Kepada }\end{array}$ & 1126 p ISSN : & 2442-448X & & \\
Masyarakat & & & \\
\hline
\end{tabular}

kriminalitas. Jumlah remaja di Indonesia juga terbilang cukup besar yaitu mencapai 63,4 juta atau $26,7 \%$ dari total penduduk. Hal yang menggambarkan adanya risiko terjadi peningkatan pelanggaran hukum (Wahyuni \& Rahmadewi, 2011).

Sholichatun (2010) menyatakan bahwa sekitar 78.000 remaja yangtersebar menurut wilayah provinsi di Indonesia berhadapan dengan permasalahan hukum. Banyak diantaranya dengan berhadapan dalam kasus hokum tersebut kemudian membuat remaja menjadi tahanan atau narapidana dan ditempatkan di Lembaga Pemasyarakatan Khusus Anak (LPKA).

Kenakalan remaja memiliki sifat psikis, interpersonal, antarpersonal, dan kultural sebab perilaku kenakalan selalu berlangsung dalam konteks antarpersonal dan sosio-kultural (Kartono, 2010). Individu menjadi faktor utama dalam memilih dan menentukan eksistensi dirinya dalam membentuk karakter agresif, asertif, atau pasif.

Beberapa hasil Penelitian (Gillen, 2003; Uyun \& Hadi, 2005; Sert, 2003; Marini \& Andriani, 2005; Sikone, 2007; Puspitawati, 2009) menunjukkan bahwa para remaja terjerumus kedalam hal negatif seperti tawuran, narkoba, seks bebas, salah satunya disebabkan oleh kepribadian yang lemah yaitu ketidakmampuan para remaja untuk bersikap asertif. Perilaku asertif bagi remaja bermanfaat untuk memudahkan bersosialisasi dalam lingkungannya, menghindari konflik karena bersikap jujur dan terus terang, dan dapat menyelesaikan masalah yang dihadapi secara efektif. Kondisi ini dalam pandangan Habermas (1979), disebut distorsi komunikasi yaitu ketidakmampuan para remaja memahami atau sengaja tidak mau untuk menyepakati aturan-aturan budaya, masyarakat, dan komunitas, sehingga para remaja terlibat dalam perilaku negative. Dalam aturan-aturan tersebut dapat ditelusuri latar belakang sosial dan kultural yang memberikan kemungkinan membayangkan dirinya dalam posisi orang lain.

Dalam kaitannya dengan keberadaan remaja yang menjadi narapidana, menurut Kartono (2005) pemenjaraan akan mengakibatkan konflik-konflik batin yang serius, terutama sekali pada para remaja yang baru pertama kali masuk penjara, karena mengalami patah mental yang disebabkan oleh isolasi sosial dalam penjara. Remaja yang dipenjarakan merasa dikucilkan dan dikutuk oleh masyarakat didalam penjara dan juga oleh masyarakat luar pada umum-nya. Remaja yang dipenjarakan pada umumnya secara mental tidak siap menghadapi realitas yang ada di dalam penjara, yaitu atas tindakantindakan yang dilakukan oleh sesama remajapenghuni Lembaga Pemasyarakatan Anak. Selain itu akan muncul perasaan menyesal atas perbuatan dan kesalahan yang telah dilakukan bahkan ada 


\begin{tabular}{|c|c|c|c|c|}
\hline Prosiding & e ISSN : 2581- & & & \\
Penelitian \& & Vol 6, No: 2 & Hal: $123-180$ & Juli 2019 \\
Pengabdian & 1126 p ISSN : & 2442-448X & & \\
Kepada & & & \\
Masyarakat & & & \\
\hline
\end{tabular}

perasaan membenci dirinya sendiri.

Keberadaan remaja di dalam Lembaga Pemasyarakatan Anakdihadapkan pada berbagai permasalahan yang sulit untuk dihadapi dan membuat mereka terpaksa belajar untuk dapat menghadapinya seorang diri serta berusaha untuk tetap dapat mempertahankan kepercayaan diri merekasaat berhadapan dengan teman-temannya dan petugas di dalam Lembaga Pemasyarakatan Khusus Anak (LPKA).

Masa remaja merupakan masa di mana seorang individu menghadapi banyak perubahan dan tantangan dalam dirinya. Banyak diantara remaja tidak dapat menghadapi perubahan yang terjadi pada dirinya dengan baik, begitu pun dengan ketidakmampuan remaja dalam menghadapi berbagai tantangan yang muncul dari lingkungan sosialnya, sehingga menimbulkan permasalahan yang dirasa kompleks bagi diri remaja.

Masalah yang sulit mulai dari berurusan dengan perubahan pada penampilan fisik mereka hingga diterima dalam kelompok pertemanannya akan sangat berpengaruh terhadap perilaku remajadi hadapan umum. Seberapa baik remaja berperilakudi dalam lingkungan sekolah dan dalam berbagai lingkungan lain di kehidupan mereka, serta kemampuan mereka dalam memenuhi harapan keluargaakan menjadikan remaja lebih dapat menerima diri mereka sendiri. Dengan menjadi lebih menerima diri mereka sendiri, remaja menjadi lebih siap untuk menghadapi halhal yang menyakitkan yang dapat merusak kepercayaan diri mereka.Salah satu cara untuk meningkatkan kepercayaan diri adalah dengan sikap dan perilaku asertif yang pada akhirnya komunikasi yang efektif akan tercapai.

\section{1) PelatihanAsertif (Assertiveness Training)}

dapat Salah satu upaya yang untukmeningkatkankepercayaar i pada remaja adalahdengan bersikap dan berperilaku secara asertif, sehingga akan menghasilkan komunikasi yang efektif.Menurut Sikone (2007)Sikap dan perilaku asertif bagi remaja sangatlah penting karena beberapa alasan sebagai berikut: pertama, sikap dan perilaku asertif akan memudahkan remaja tersebut bersosialisasi dan menjalin hubungan dengan lingkungan secara efektif. Kedua, dengan kemampuan untuk mengungkapkan apa yang dirasakan dan diinginkannya secara langsung dan terus terang maka para remaja dapat menghindari munculnya ketegangan dan perasaan tidak nyaman akibat menahan dan menyimpan sesuatu yang ingin diutarakannya. Ketiga, dengan memiliki sikap asertif, maka para remaja dapat dengan mudah mencari solusi dan penyelesaian dari berbagai kesulitan atau permasalahan yang dihadapinya secara lebih efektif. Keempat, asertivitas akan membantu remaja untuk meningkatkan kemampuan kognitifnya, memperluas wawasannya tentang lingkungan, 


\begin{tabular}{|c|c|c|c|c|}
\hline Prosiding & e ISSN : 2581- & & & \\
Penelitian \& & Vol 6, No: 2 & Hal: $123-180$ & Juli 2019 \\
Pengabdian & I126 p ISSN : & 2442-448X & & \\
Kepada & & & \\
Masyarakat & & & \\
\hline
\end{tabular}

dan tidak mudah berhenti pada sesuatu yang tidak diketahuinya (memiliki rasa keingintahuan yang tinggi).

Latihan asertif (Assertive Training) atau latihan keterampilan sosial adalah salah satu dari sekian banyak topik yang tergolong popular dalam terapi perilaku (behavior therapy).Asertivitas merupakan kemampuan seseorang untuk mengekspresikan diri, pandangan-pandangan dirinya, dan menyatakan keinginan dan perasaan diri secara langsung, jujur, dan spontan tanpa merugikan diri sendiri dan melanggar hak orang lain. Asertivitas dalam perspektif pendidikan merupakan domain keterampilan sosial (social skills) diantara kerja sama (cooperation), tanggung jawab (responsibility), dan self-control (Sivin-Kachala \& Bialo, 2009), empathy (Elliot \&Gresham dalam Golden, 2002), problem behavior (Chong \& Li, Jen-Yi, 2008). Dengan demikian, asertivitas merupakan kemampuan untuk mengungkapkan hak dan kebutuhan secara positif dan konstruktif tanpa melanggar hak orang lain. Ciri seseorang yang memiliki perilaku asertif adalah hubungan yang dilakukan merasa lebih percaya diri, mendapatkan rasa hormat dari orang lain melalui jalinan komunikasi secara langsung, terbuka, dan jujur. Asertivitas bermanfaat bagi individu untuk menjaga kejujuran dalam komunikasi, mampu untuk mengendalikan diri, dan meningkatkan kemampuan dalam pengambilan keputusan.
Menurut Goldstein (1986) latihan asertif merupakan rangkuman yang sistematis dari ketrampilan, peraturan, konsep atau sikap yang dapat mengembangkan dan melatih kemampuan individu untuk menyampaikan pikiran, perasaan, keinginan dan kebutuhannya dengan penuh percaya diri dan kejujuran sehingga dapat berhubungan baik dengan lingkungan sosialnya. hal-hal yang dapat dibantu dengan latihan asertif antara lain :

1. Tidak dapat menyatakan kemarahannya atau kejengkelannya.

2. Mereka yang sopan berlebihan dan membiarkan orang lain mengambil keuntungan dari padanya.

3. Mereka yang mengalami kesulitan berkata "tidak"

4. Mereka yang merasakan tidak punya hak untuk menyatakan pendapatnya.

5. Kecemasan dalam diri individu, seperti:

a. Merasa tidak pantas dalam pergaulan sosial

b. Takut untuk ditinggalkan

c. Kesulitan mengekspresikan perasaan cinta kepada orang-orang disekitarnya.

Dalam membangun perilaku asertif terdapat beberapa pendekatan yang dapat ditempuh. Salah satunya adalah Formula 3A, yang terangkai dari tiga kata Appreciation, Acceptance, Accommodating (Susanto, 2005):

a. Appreciation berarti menunjukkan penghargaan terhadap kehadiran orang 


\begin{tabular}{|c|c|c|c|c|}
\hline Prosiding & e ISSN : 2581- & & & \\
Penelitian \& & Vol 6, No: 2 & Hal: $123-180$ & Juli 2019 \\
$\begin{array}{c}\text { Pengabdian } \\
\text { Kepada }\end{array}$ & 1126 p ISSN : & 2442-448X & & \\
Masyarakat & & & \\
\hline
\end{tabular}

lain, dan tetap memberikan perhatian sampai pada batas-batas tertentu atas apa yang terjadi pada diri mereka. Mereka pun, seperti kita, tetap membutuhkan perhatian orang lain. Dengan demikian, agar mereka mau memperhatikan, memahami, dan menghargai kita, maka sebaiknya kita mulai dengan terlebih dulu menunjukkan perhatian, pemahaman, dan penghargaan kepada mereka.

b. Acceptance adalah perasaan mau menerima, memberikan arti sangat positif terhadap perkembangan kepribadian seseorang, yaitu menjadi pribadi yang terbuka dan dapat menerima orang lain sebagaimana keberadaan diri mereka masing-masing. Dalam hal ini, kita tidak memiliki tuntutan berlebihan terhadap perubahan sikap atau perilaku orang lain (kecuali yang negatif) agar ia mau berhubungan dengan kita. Tidak memilihmilih orang dalam berhubungan, dengan tidak membatasi diri hanya pada keselarasan tingkat pendidikan, status sosial, suku, agama, keturunan, dan latar belakang lainnya.

c. Accomodating. Menunjukkan sikap ramah kepada semua orang, tanpa terkecuali, merupakan perilaku yang sangat positif. Keramahan senantiasa memberikan kesan positif dan menyenangkan kepada semua orang yang kita jumpai. Keramahan membuat hati kita senantiasa terbuka, yang dapat mengarahkan kita untuk bersikap akomodatif terhadap situasi dan kondisi yang kita hadapi, tanpa meninggalkan kepribadian kita sendiri.

Beberapa manfaat di atas mengindikasikan perlunya sikap ini ditanamkan sejak dini bagi para remaja karena asertivitas bukan merupakan sesuatu yang lahiriah tetapi lebih merupakan pola sikap dan perilaku yang dipelajari sebagai reaksi terhadap berbagai situasi sosial yang ada di lingkungan. Hal ini seperti yang dikatakan oleh Rathus \& Nevis (1982) perilaku asertif bukan bawaan ataupun muncul secara kebetulan pada tahap perkembangan individu, namun merupakan pola-pola yang dipelajari sebagai reaksi terhadap situasi sosial dalam kehidupannya. Asertivitas ini dalam kenyataannya berkembang sejalan dengan usia seseorang, sehingga penguasaan sikap dan perilaku pada periodeperiode awal perkembangan akan memberikan dampak yang positif bagi periode-periode selanjutnya. Individu yang asertif ditandai oleh kemampuan mengenal diri sendiri dengan baik, mengetahui kelebihan dan kekurangannya serta menerima semua itu seperti apa adanya sehingga pada gilirannya individu mampu merencanakan tujuan hidupnya, mempunyai rasa percaya diri yang tinggi, mampu mengambil keputusan. Individu yang tidak asertif cenderung bersifat emosional, tidak jujur, tidak terbuka, terhambat dan menolak diri sendiri (Bloom, 1985)

\section{2) Kepercayaan Diri (self confidence)}

Kumara (dalam Ghufron, 2014:34) menyatakan kepercayaan diri merupakan ciri kepribadian yang mengandung arti keyakinan terhadap kemampuan diri sendiri. Kepercayaan diri merupakan suatu keyakinan dan sikap seseorang terhadap kemampuan pada dirinya sendiri dengan menerima secara 


\begin{tabular}{|c|c|c|c|c|}
\hline Prosiding & e ISSN : 2581- & & & \\
Penelitian \& & Vol 6, No: 2 & Hal: $123-180$ & Juli 2019 \\
$\begin{array}{c}\text { Pengabdian } \\
\text { Kepada }\end{array}$ & 1126 p ISSN : & V442-448X & & \\
Masyarakat & & & \\
\hline
\end{tabular}

apa adanya baik positif maupun negatif yang dibentuk dan dipelajari melalui proses belajar proses belajar dengan tujuan untuk kebahagiaan dirinya.

Kepercayaan diri adalah modal dasar seorang manusia dalam memenuhi berbagai kebutuhan sendiri. Seseorang memunyai kebutuhan untuk kebebasan berpikir dan berperasaan akan tumbuh menjadi manusia dengan rasa percaya diri. Salah satu langkah pertama dan utama dalam membangun rasa percaya diri dengan memahami dan meyakini bahwa setiap manusia memunyai kelebihan dan kelemahan masing-masing. Kelebihan yang ada di dalam diri seseorang harus dikembangkan dan dimanfaatkan agar menjadi produktif dan berguna bagi orang lain (Hakim, 2002).Berdasarkan definisi yang telah disebutkan di atas, maka dapat disimpulkan bahwa kepercayaan diriadalah suatu sikap dan keyakinan pada diri sendiri akan kemampuan yang dimilikinya dan muncul karena adanya sikap positif terhadap kemampuannya, sehingga tidak perlu ragu-ragu dalam mengambil keputusan dan tidak terpengaruh oleh orang lain.Menurut Lecron (dalam Kusumasari, 1997:7) kepercayaan diri adalah keyakinan atau rasa percaya yang dimiliki seseorang terhadap dirinya sendiri yang dapat menyebabkan seseorang mampu mengambil keputusan dengan tepat dan bijaksana.

Santrock (2003:336-338) mengungkapkan faktor-faktor yang mempengaruhi kepercayaan diri yaitu:

a. Penampilan fisik Sejumlah peneliti telah menemukan penampilan fisik merupakan suatu kontributor yang sangat berpengaruh pada rasa percaya diri remaja (Adams, dkk dalam Santrock, 2003:336). Sebagai contoh adalah pada penelitian Harter, penampilan fisik secara konsisten berkorelasi paling kuat dengan rasa percaya diri secara umum, yang baru kemudian diikuti oleh penerimaan sosial teman sebaya.

b. Konsep diri Harter (dalam Santrock, 2003:337) juga menemukan adanya hubungan yang kuat antara penampilan fisik dengan harga diri secara umum yang tidak hanya dimasa remaja tapi juga sepanjang masa hidup, dari masa kanakkanak awal hingga usia dewasa pertengahan. Pada salah satu penelitian baru-baru ini dikemukankonsep diri remaja yang berhubungan dengan ketertarikan fisik merupakan faktor terkuat untuk meramalkan rasa percaya diri secara keseluruhan dari remaja (Lord \& Eccles dalam Santrock, 2003:337).

c. Hubungan dengan orang tua Pada suatu penelitian yang luas mengenai hubungan orang tua dan anak dengan rasa percaya diri, terdapat suatu alat ukur rasa percaya diri yang diberikan kepada anak laki-laki, dan kemudian anak lakilaki beserta ibunya diwawancarai mengenai hubungan keluarga mereka (Coopersmith dalam Santrock, 2003:338). Berdasarkan pengukuran tersebut, berikut ini adalah atribut-atribut dari orang tua yang berhubungan dengan tingkat rasa percaya diri yang tinggi dari anak laki-laki:

- Ekspresi rasa kasih sayang

- Perhatian terhadap masalah yanng dihadapi oleh anak

- Keharmonisan dirumah

- Partisipasi dalam aktivitas bersama keluarga

- Kesediaan untuk memberikan pertolongan yang kompeten dan 


\begin{tabular}{|c|c|c|c|c|}
\hline Prosiding & e ISSN : 2581- & & & \\
Penelitian \& & Vol 6, No: 2 & Hal: $123-180$ & Juli 2019 \\
$\begin{array}{c}\text { Pengabdian } \\
\text { Kepada }\end{array}$ & 2442-448X & & & \\
Masyarakat & & & \\
\hline
\end{tabular}

terarah kepada anak ketika mereka membutuhkannya

- Menetapkan peraturan yang jelas dan adil

- Mematuhi peraturan-peraturan tersebut

- Memberikan kebebasan pada anak dengan batas-batas yang telah ditentukan.

Santrock

(2003:338)

menyatakan walaupun faktor-faktor seperti ekspresi rasa kasih sayang dan memberi kebebasan kepada anak-anak dengan batas tertentu terbukti sebagai faktor penentu yang penting bagi rasa percaya diri remaja, para peneliti hanya dapat menyatakan bahawa faktor-faktor tersebut berhubungan dengan rasa percaya diri namun bukan sebagai penyebab dari tingkat rasa percaya diri anak, berdasarkan data penelitian yang menunjukkan adanya korelasi.

d. Hubungan teman sebaya Penilaian teman sebaya memiliki derajat yang tinggi pada anak-anak yang lebih tua dan remaja. Suatu penelitian menunjukkan dukungan dari teman sebaya lebih berpengaruh terhadap tingkat kepercayaan diri pada individu pada masa remaja awal daripada anak-anak, meskipun dukungan orangtua juga merupakan faktor yang penting.

\section{Metode}

Metode yang digunakan dalam melakukan kegiatan assertiveness trainingini adalah dengan menggunakan metodologi pelatihan andragogi yang mensyaratkan peserta pelatihan diposisikan sebagai orang dewasa dan didorong untuk berperan aktif dalam setiap tahapan pelatihan. Baik melalui teknik brainstrorming guna mengungkap berbagai permasalahan yang dihadapi remaja dan juga Teknik sharing pengalaman diantara sesama peserta pelatihan dan juga fasilitator pelatihan. Hal inibertujuan agar peserta pelatihan dapat melihat segala sesuatu yang terkait dengan permasalahan yang sedang dihadapi dari sudut pandang yang berbeda, hingga menemukan sudut pandang baru yang lebih positif dan dapat mengubah cara berpikir dan berperilaku mereka di kemudian hari.

\section{Hasil dan Pembahasan}

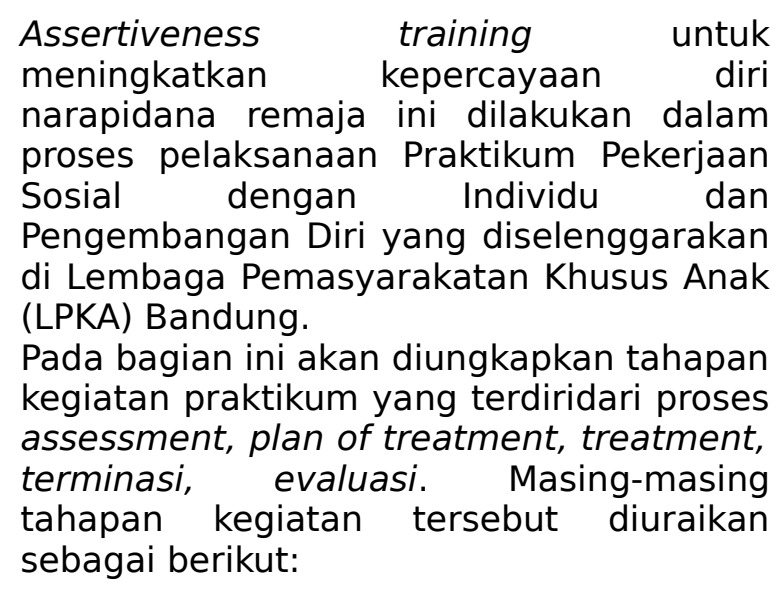

\section{1) Hasil Assesment}

Pada tahapan assessment ini praktikan menggali data dan informasi sebanyakbanyaknya terkait keberadaan diri klien, lingkungan sosial klien, potensi yang dimiliki klien serta permasalahan yang dihadapi oleh klien dengan tujuan untuk menentukan arah proses pembimbingan dan pendampingan apakah yang akan dikembangkan dalam proses praktikum ini. Dalam pelaksanaannya, kegiatan praktikum ini dapat dibagi menjadi dua aktivitas berbeda, yaitu proses pembimbingan dan pendampingan yang bertujuan untuk mengembangkan potensi pada diri klien ataukah proses bersamasama klien mencari jalan keluar dari permasalahan yang dihadapi klien. 


\begin{tabular}{|c|c|c|c|c|}
\hline Prosiding & e ISSN : 2581- & & & \\
Penelitian \& & Vol 6, No: 2 & Hal: $123-180$ & Juli 2019 \\
$\begin{array}{c}\text { Pengabdian } \\
\text { Kepada }\end{array}$ & 1126 p ISSN : & 2442-448X & & \\
Masyarakat & & & \\
\hline
\end{tabular}

Di awal pertemuan antara praktikan bersama klien dengan inisial MS, impresi yang didapatkan oleh praktikan adalah bahwa MS merupakan seorang remaja dengan sifat pemalu. Hal ini tampak dari sikap klien yang cenderung diam dan praktikan yang harus memulai pembicaraan terlebih dahulu. Ketika berbicara, klien selalu menduduk dan tidak berani menatap mata atau pun menghadap kearah praktikan.

Klien mengatakan bahwa dirinya merupakan pribadi yang tidak percaya diri dan tidak mudah untuk bersikap terbuka kepada orang yang baru dikenalnya atau orang yang berasal dari lingkungan baru.Klien juga mengatakan bahwa dirinya kurang percaya diri dan tidak berani berbicara di depan umum.

Dalam tahap asesstment praktikan mengajak klien untuk mengisi form kelebihan serta kekurangan untuk menggali potensi dan permasalahanyang dihadapi oleh klien, yaitu seperti yang tertuang dalam tabel 1 dibawah ini

Tabel 1

Kelebihan dan kekurangan pada diri klien

\begin{tabular}{|c|c|c|c|}
\hline kelebihan & kekusangoer: & $\begin{array}{c}\text { Masalah (jika } \\
\text { ada) }\end{array}$ & $\begin{array}{c}\text { Aspek-aspek } \\
\text { pribadi yang } \\
\text { ingin } \\
\text { dikembangkan }\end{array}$ \\
\hline $\begin{array}{l}\text { 1. Selalu membantu teman } \\
\text { yang sedang kesulitan } \\
\text { 2. Senang membaca novel } \\
\text { 3. Rajin menabung }\end{array}$ & $\begin{array}{l}\text { 1. } \begin{array}{l}\text { Kurang } \\
\text { percaya } \\
\text { diri }\end{array} \\
\text { 2. Suka } \\
\text { memenda } \\
\text { m emosi }\end{array}$ & 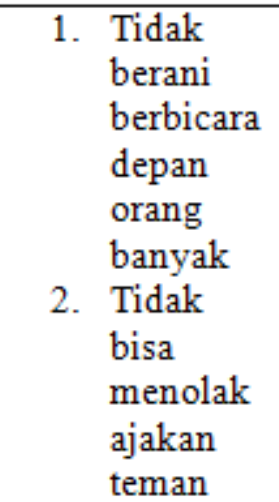 & $\begin{array}{l}\text { Ingin } \\
\text { lebih } \\
\text { percaya } \\
\text { diri dan } \\
\text { lebih } \\
\text { baik. }\end{array}$ \\
\hline
\end{tabular}

Sumber: Praktikum Pekerjaan Sosial dengan Individu dan Pengembangan Diri, 2019

Berdasarkan tabel diatas, klien dengan inisial MS memiliki kelebihan selalu membantu teman yang sedang kesulitan, hal ini dijelaskan oleh klien berdasarkan berbagai pengalaman yang ia ceritakan tentang membantu teman-temannya. Senang membaca novel ini juga termasuk hobi klien yang senang mengoleksi beberapa buku novel salah satu penulis favoritnya adalah Raditya Dika. Rajin menabung ini dijelaskan oleh klien bahwa ia sering membeli sepatu yang ia inginkan hasil daru uang tabungan tersebut. kekurangan yang dimiliki oleh klien adalah rasa kurang percaya diri dan suka memendam emosi. Hal tersebut 


\begin{tabular}{|c|c|c|c|c|}
\hline Prosiding & e ISSN : 2581- & & & \\
Penelitian \& & Vol 6, No: 2 & Hal: $123-180$ & Juli 2019 \\
$\begin{array}{c}\text { Pengabdian } \\
\text { Kepada }\end{array}$ & 2426 p ISSN : & & & \\
Masyarakat & & & & \\
\hline
\end{tabular}

menimbulkan masalah yang dihadapi klien yaitu tidak berani berbicara didepan orang banyak dan juga tidak bisa menolak ajakan teman. Klien bercerita bahwa pertama kali ia mencoba rokok, minuman alkohol, dan narkoba itu karena diajak oleh temannya. Aspek-aspek pribadi yang ingin dikembangkan klien adalah ia ingin lebih percaya diri dan menjadi pribadi yang lebih baik.

Gambar 1

Genogram klien

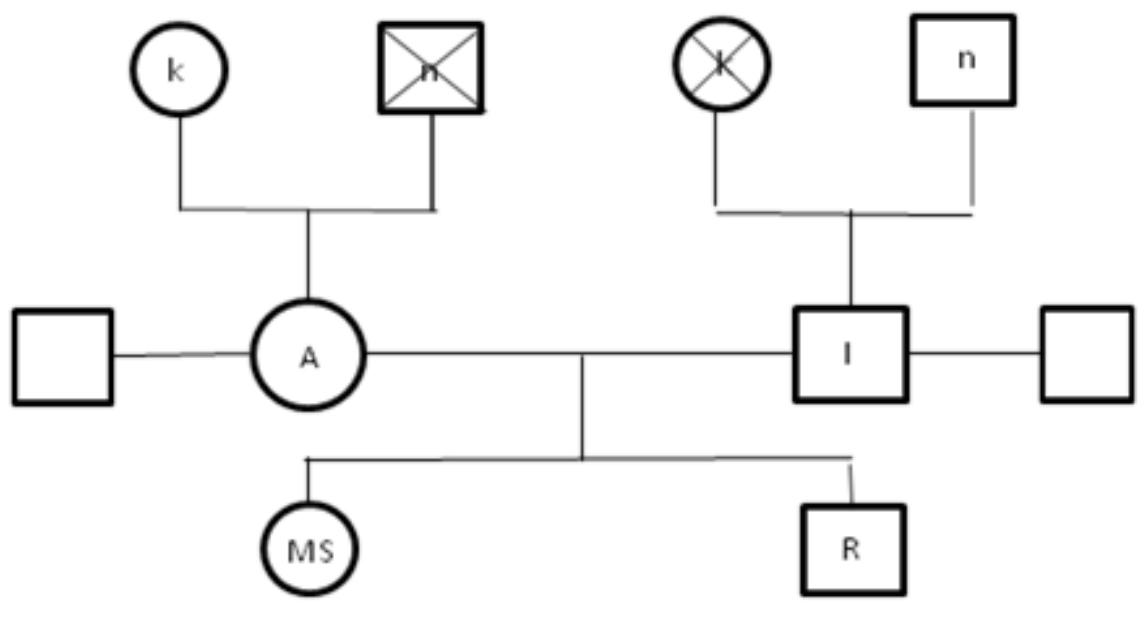

Ketesanałer: PraktikumPekerjaanSosialdenganIndividu dan PengembanganDiri, 2019

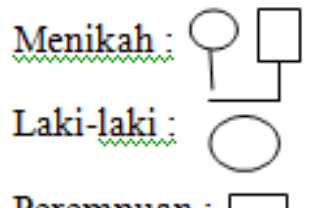

Perempuan:

Meninggal : 


\begin{tabular}{|c|c|c|c|c|}
\hline Prosiding & e ISSN : 2581- & & & \\
Penelitian \& & Vol 6, No: 2 & Hal: $123-180$ & Juli 2019 \\
$\begin{array}{c}\text { Pengabdian } \\
\text { Kepada }\end{array}$ & 2426 p ISSN : & & \\
Masyarakat & & & & \\
\hline
\end{tabular}

Berdasarkan genogram yang telah dibuat oleh klien, maka dapat dipaparkan hubungan keluarga yang dimiliki oleh klien adalah sebagai berikut: Klien (MS) merupakan anak pertama dari 2 bersaudara. Klien berusia 18 tahun sebagai pelajar di bangku SMK. Klien mempunyai adik perempuan (R) yang berusia 12 tahun sebagai pelajar di bangku SMP. Klien saat ini berada di lapas anak sukamiskin berada jauh dari ayah (A), ibu (I), dan adik (R) yang tinggal di lembang. Ayah klien bekerja sebagai tour guidedan ibu klien bekerja sebagai marketing di sebuah hotel di kawasan Bandung. Nenek dari Ayah dan Kakek dari Ibu klien keduanya sudah meninggal dunia.

Hubungan dengan keluarga berdasarkan penuturan klien dirasakan baik-baik saja namun tidak begitu dekat. Ayah klien memiliki satu saudara kandung dan Ibu klien memiliki satu saudara kandung. Hubungan antara keluarga dari pihak ayah maupun pihak ibu klien dirasakan oleh klien cukup dekat meskipun jarang bertemu.

Setiap salah satu anggota keluarga klien ada yang berulang tahun, selalu merayakan dengan makan-makan bersama ayah, ibu dan adiknya. Klien mengatakan bahwa keluarganya jarang mengisi waktu liburan bersama karena kedua orangtua klien yang masih sibuk bekerja. Hubungan klien dengan adiknya cukup baik namun klien jarang berbicara kepada adiknya karena klien sering menghabiskan waktunya diluar rumah bersama teman-teman. Hubungan klien dengan ayah tidak terlalu dekat, hal ini disampaikan klien bahwa klien pernah diusir dari rumah selama 2 minggu karena ketahuan memakai narkoba. Hubungan klien dengan ibunya cukup dekat, itu dikatakan oleh klien karena ibunya tetap memberikan uang jajan kepada klien meskipun klien tidak ada dirumah selama 2 minggu.

Hubungan klien dengan teman dekatnya dari TK pun sangat dekat, klien mengatakan bahwa ia sering membantu teman yang sedang kesulitan namun hal ini berdampak pada rasa solidaritas yang terlalu tinggi. Klien tidak bisa menolak ajakan temannya untuk pergi ke tempat hiburan malam, hal itu karena klien khawatir temannya marah atau sakit hati sehingga ia selalu menuruti ajakan temannya. Klien menceritakan kejadian ia membantu temannya yang sedang dipukuli oleh orang lain kemudian klien ikut membalas memukuli orang lain tersebut yang memukuli teman klien. Klien juga mengatakan bahwa dirinya kurang percaya diri dan tidak berani berbicara didepan umum.

\section{2) Plan of Treatment (POT)}

Intervensi yang akan diberikan praktikan pada klien adalah memperbaiki pemikiran klien menjadi lebih positif, meningkatkan rasa percaya diri dan mengetahui apa yang harus dilakukan dalam menghadapi masalah. Dengan demikian, plan of treatment yang akan dilakukan adalah sebagai berikut:

1. Tujuan: Praktikan membantu untuk mendorong klien agar mampu membuat pikiran alternatif yang positif terhadap suatu kondisi 


\begin{tabular}{|c|c|c|c|c|}
\hline Prosiding & e ISSN : 2581- & & & \\
Penelitian \& & Vol 6, No: 2 & Hal: $123-180$ & Juli 2019 \\
$\begin{array}{c}\text { Pengabdian } \\
\text { Kepada }\end{array}$ & 2426 p ISSN : & & \\
Masyarakat & & & & \\
\hline
\end{tabular}

tertentu, agar klien dapat memilah pikiran seperti apa yang seharusnya klien gunakan dalam menghadapi permasalahannya dan klien dapat percaya diri dan mampu berkomunikasi depan umum.

2. Praktikan menjelaskan kegunaan dan manfaat pelatihan asertif, yaitu untuk klien dalam menghasilkan pikiran alternatif yang lebih positif untuk menghadapi situasi yang menjadi permasalahan bagi klien.

3. Praktikan berkomunikasi dengan klien mengenai proses yang akan dilakukan oleh klien untuk mengatasi permasalahannya dengan menggunakan pelatihan asertif

4. Proses pelatihan asertif dilakukan oleh klien dalam waktu lima minggu yang disertai dengan pendampingan dari praktikan untuk setiap minggunya.

\section{3) Treatment}

Berdasarkan hasil asessment dan plan of treatment, maka intervensi yang akan dilakukan praktikan terhadap klien mengenai permasalahan yang dialami klien adalah dengan menggunakan pelatian asertif atau Assertive Training.Latihan asertif menggunakan prosedur-prosedur bermain peran. Kecakapan-kecakapan bergaul yang baru akan diperoleh sehingga individu-individu diharapkan mampu belajar untuk mengungkapkan perasaan-perasaan dan pikiran-pikiran mereka secara lebih terbuka.

Adapun langkah-langkah dalam strategi latihan asertif adalah sebagai berikut:
1. Rasional strategi. Yaitu praktikan memberikan rasional/ menjelaskan maksud penggunaan strategi. Konselor memberikan overview tahapantahapan implementasi strategi.

2. Identifikasi keadaan yang menimbulkan persoalan. Yaitu praktikan meminta klien menceritakan secara terbuka permasalahan yang dihadapi dan sesuatu yang dilakukan atau dipikirkan pada saat permasalahan timbul.

3. Membedakan perilaku asertif dan tidak asertif serta mengeksplorasi target. Yaitu praktikan dan klien membedakan perilaku asertif dan perilaku tidak asertif serta menentukan perubahan perilaku yang diharapkan.

4. Bermain peran, pemberian umpan balik serta pemberian model perilaku yang lebih baik. Klien bermain peran sesuai dengan permasalahan yang dihadapi. Praktikan memberi umpan balik secara verbal, pemberian model perilaku yang lebih baik, pemberian penguat positif dan penghargaan.

5. Melaksanakan latihan dan praktik Klien mendemonstrasikan perilaku yang asertif sesuai dengan target perilaku yang diharapkan.

6. Mengulang latihan Klien mengulang latihan kembali tanpa bantuan pembimbing

7. Tugas rumah dan tindak lanjut praktikan memberi tugas rumah pada klien (home assignment), dan meminta klien mempraktekkan perilaku yang diharapkan dan memeriksa perilaku target apakah sudah dilakukan dalam kehidupan seharihari.

Setelah dilakukan treatment diatas selama 5 minggu terlihat perubahan pada tingkat 


\begin{tabular}{|c|c|c|c|c|}
\hline Prosiding & e ISSN : 2581- & & & \\
Penelitian \& & 1126 p ISSN : & Vol 6, No: 2 & Hal: $123-180$ & Juli 2019 \\
$\begin{array}{c}\text { Pengabdian } \\
\text { Kepada }\end{array}$ & $2442-448 X$ & & & \\
Masyarakat & & & \\
\hline
\end{tabular}

kepercayan diri klien (MS) mampu mengekspresikan pikiran, perasaan, dan kebutuhan dirinya, baik secara verbal maupun non verbal secara bebas, tanpa perasaan takut, cemas, dan khawatir. Klien juga mampu untuk berkomunikasi secara terbuka, langsung, jujur, terus terang sebagaimana mestinya.

\section{4) Terminasi}

Setelah intervensi dan evaluasi terhadap klien telah dilakukan, tahapan selanjutnya adalah terminasi. Terminasi ini dilakukan karena telah berakhirnya masa praktikum mikro dan target minimal dari intervensi ini sudah tercapai. Target minimal dari praktikan dalam intervensi ini, yaitu klien menjadi percaya diri dan mampu berkomunikasi di depan umum yang tunjukkan pada saat penutupan praktikum di lapas, klien (MS) berani maju ke depan untuk menjawab pertanyaan dengan tegas, jelas dan percaya diri.

Dalam melakukan terminasi ini, praktikan menjabarkan hal-hal yang sudah dilakukan dari awal sampai akhir dilakukannya intervensi. Praktikan pun menjabarkan hasilhasil yang sudah tercapai saat intervensi dilakukan. Pada tahap terminasi klien pun merasa bahwa apa-apa yang ia dapatkan sesuai dengan apa yang ia harapkan dalam menyikapi berbagai persoalan.

\section{5) Evaluasi}

Evaluasi dilaksanakan setelah proses treatment selesai dilakukan. Dalam proses evaluasi ada beberapa kriteria yang dilakukan untuk menilai apakah proses pendampingan telah berjalan dengan sesuai dengan rencana.

Dalam proses pendampingan ini klien mengatakan ada banyak manfaat yang ia rasakan. Pertama klien mempunyai teman untuk bercerita apa saja tentang masalahnya. Kemudian pendampingan ini membantu klien keluar dari rasa malu dan tidak percaya dirinya. Hal tersebut diakui oleh klien. Secara jujur bahwa sejak pertama kali pendampingan ini dimulai telah terjadi perubahan dalam diri. la lebih mampu mengontrol diri dan pikiran. Dulunya klien tidak mau mengatakan pendapatnya walaupun bisa menjawab dan kini ia mengatakan sudah mulai lebih berani untuk menyampaikan pendapat. Klien mengatakan bahwa dalam pendampingan ini, dengan pelatihan asertif ini banyak membantu menghadapi rasa malu dan tidak percaya diri meskipun masih sedikit kaku untuk dilakukan. la mengaku masih harus banyak latihan dalam teknik tersebut.

Tujuan dari intervensi telah tercapai, klien mampu untuk menyampaikan pikiran, perasaan, keinginan dan kebutuhannya dengan penuh percaya diri dan kejujuran sehingga dapat berhubungan baik dengan lingkungan sosialnya. Klien (MS) juga harus sering melatih dirinya untuk mengendalikan rasa tidak percaya diri agar klien dapat benar-benar memiliki sikap asertif.

\section{Simpulan dan Saran (Conclusion and Suggestion)}

Klien memiliki permasalahan tidak percaya diri yang menjadifokusdalam proses treatment dalam kegiatan praktikumini. Klien merasa malu berbicara dengan orang baru, dan depan banyak orang, klien merasa tidak percaya diri. Dari persoalan tersebut praktikanbersamaklienberusahamengatasi persoalan yang dirasamengganggukliendenganmengguna kan teknik pelatihan asertif (Assertiveness Training). 


\begin{tabular}{|c|c|c|c|c|}
\hline Prosiding & e ISSN : 2581- & & & \\
Penelitian \& & 1126 p ISSN : & Vol 6, No: 2 & Hal: $123-180$ & Juli 2019 \\
$\begin{array}{c}\text { Pengabdian } \\
\text { Kepada }\end{array}$ & $2442-448 X$ & & & \\
Masyarakat & & & \\
\hline
\end{tabular}

Hasil yang diperoleh dengan dilakukannya assertiveness training dan proses pendampingan terhadap klien adalah bahwa klien telah mampu untuk mengekspresikan pikiran, perasaan, dan kebutuhan dirinya, baik secara verbal maupun non verbal secara bebas, tanpa perasaan takut, cemas, dan khawatir. Klien juga mampu untuk berkomunikasi secara terbuka, langsung, jujur, terus terang sebagai mana mestinya. Dengan demikian, praktikanmemberikan saran kepadaklien untuk mempertahankan sikap asertifnya dan dapat terus meningkatkan rasa kepercayaan diri klien.

\section{UCAPAN TERIMA KASIH}

Dalam kesempatan ini penulis ingin menyampaikan ucapan terimakasih kepada pihak yang telah memberikan bantuan, dorongan, serta bimbingan sehingga penulis dapat menyelesaikan

\section{DAFTAR PUSTAKA}

Bloom, L.Z.; Coburn, K. \& Pearlam, J. 1985. The Asertive Woman. New York: Dell Publishing Co.Inc.

Chong, J. Y. \& Li, Jen-Ye. (2008). Social skills in Children with Special Needs, with and without Mainstream Education in Singapore. Singapura: National Institute of Education, Nanyang Technological University.

Gillen, T. (2003). Assertiveness, London: Management Shapers, Chartered Institute of Personnel and Development (CIPD).

Golden, L. (2002). Evaluation of the Efficacy of a Cognitive Behavioral Program for Offenders on Probation: thinking for a Change. Dallas: University of Texas Southwestern Medical Center. penulisan laporan praktikum mikro ini. Penulis menyampaikan terima kasih setulus-tulusnya kepada:

1) Allah SWT karena atas rahmat-Mu penulis masih diberi kesehatan baik lahir maupun batin, sehingga Laporan Praktikum Mikro ini dapat terselesaikan dengan baik.

2) Tim Dosen Praktikum Mikro yang telah membimbing saya.

3) Ibu Meilanny Budiarti Santoso, S.Sos., SH., M.Si selaku supervisor yang telah banyak membantu dalam bimbingan selama proses praktikum berlangsung.

Demikian laporan praktikum mikro ini disusun, akhir kata penulis berharap laporan inidapat bermanfaat bagi penulis khususnya dan bagi semua pihak pada umumnya

Ghufron, M. N \& Risnawita, R. (2014). Teori-Teori Psikologi. Jogjakarta: Arruzz Media

Habermas, Jurgen. (1979). "What is Universal Pragmatics?", dalam Jürgen Habermas Commnication and the Evolution of Society, Beacon Press: Boston

Hakim, T. 2002. Mengatasi Rasa Percaya Diri. Jakarta : Puspaswara.

Kartono, K. (2010). Patologi Sosial 2: Kenakalan Remaja, Cetakan ke-9, Jakarta: Rajawali Pers.

Kusumasari. (1997). Kepercayaan Diri dan Minat Membeli T-shirt Unik pada Remaja. Yogyakarta: Fakultas Psikologi UGM.

Marini, L., \& Andriani, E. (2005). Perbedaan Asertivitas Remaja Ditinjau dari Pola Asuh Orang Tua", PSIKOLOGIA, I(2) 


\begin{tabular}{|c|c|c|c|c|}
\hline Prosiding & e ISSN : 2581- & & & \\
Penelitian \& & 1126 p ISSN : & Vol 6, No: 2 & Hal: $123-180$ & Juli 2019 \\
$\begin{array}{c}\text { Pengabdian } \\
\text { Kepada }\end{array}$ & $2442-448 X$ & & & \\
Masyarakat & & & \\
\hline
\end{tabular}

Puspitawati, H. (2009). Pengaruh Komunikasi Keluarga, Lingkungan Teman Dan Sekolah Terhadap Kenakalan Pelajar Dan Nilai Pelajaran Pada Sekolah Menengah 01 Kota Bogor, PEKSOS: Jurnal IImiah Pekerjaan Sosial, 7(2).

Rathus, S.A. \& Nevis, J.S. 1982. Behavior Therapy, Strategy for Solving Problems in Living. New York: The Hearst of Corp.

Santrock, Jhon, W. (2003). Adolescene: Perkembangan Remaja. Terjemahan oleh Shinto B. Adelar dan Sherly Siragih. Jakarta: Erlangga.

Sert, A. G. (2003). The Effect of an Assertiveness Training on the Assertiveness and Self-Esteem Level of 5th Grade Children, A Thesis Submitted to The Graduate School of Social Sciences ofMiddle East Technical University, in Partial Fullfilment of The Requirements for the Degree of Master of Science in The Department of Educational Sciences, June 2003.

Sholichatun, Y. (2011). Stres dan strategi coping pada anak didik di lembaga pemasyarakatan anak. Jurnal Psikologi Islam, 8 (1), 23-42.

Sikone, S. (2007). Menanamkan Sikap Asertif di Sekolah, Diunduh dari: http://id. shvoong.com/socialsciences/1685406- menanamkansikap-asertifdisekolah/\#ixzzla0PzgKIW,

Sivin-Kachala, J., \& Bialo, E. (2009). IESD Comprehensive Technical Report, Evaluation of the Social Skills of Full-Time, Online Public School Students, New York: Interactive Educational System Design (IESD) Inc.

Susanto. 2005. Memilih Asertif, Bukan Agresif. Jakarta Consulting Group
Uyun, Q., \& Hadi, S. (2005). “Pelatihan Asertivitas untuk Meningkatkan Ketahanan Isteri terhadap Tindak Kekerasan Suami", SOSIOSAINS, 18(1).

Wahyuni, D., \& Rahmadewi, R. (2011). Kajian profil penduduk remaja (1024 tahun): Ada apa dengan remaja. Policy Brief Pusat Penelitian dan Pengembangan KependudukanBKKBN, I (6), 1-4 